DOI: https://doi.org/10.31933/jimt.v2i2 Received: 8 November 2020, Revised: 25 November 2020, Publish: 23 Desember 2020

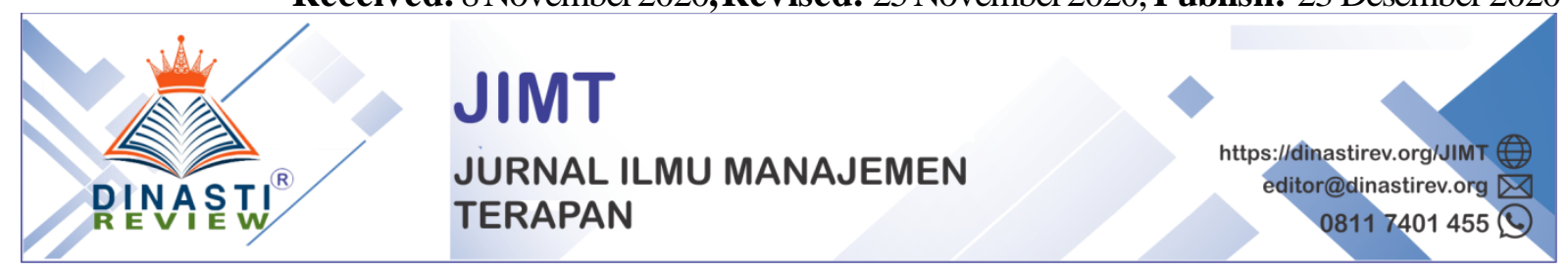

\title{
DETERMINASI KEPUASAN KERJA DAN KINERJA PEGAWAI: ANALISIS MUTASI PEGAWAI DAN PENEMPATAN PEGAWAI (LITERATURE REVIEW MANAJEMEN SUMBERDAYA MANUSIA)
}

\author{
Rafles Ricadson Purba \\ Student of Universitas Terbuka, Indonesia, rafles.ricadson@gmail.com
}

\section{Corresponding Author: Rafles Ricadson Purba}

Abstrak: Terdapat hubungan positif yang sangat signifikan antara kepuasan kerja dengan kinerja karyawan. Dapat diartikan bahwa semakin tinggi nilai kepuasan kerja seseorang karyawan maka akan semakin tinggi pula kinerja karyawan, sebaliknya semakin rendah kepuasan kerja maka semakin rendah pula kinerja karyawan. Berdasarkan pengalaman empirik banyak mahasiswa dan dosen muda juga peneliti lainnya, kesulitan untuk mencari artikel pendukung dalam riset sebagai penelitian terdahulu atau sebagai penelitian yang relevan. Artikel sebagai peneliti yang relevan diperlukan untuk memperkuat teori yang di teliti, untuk melihat hubungan antar variable dan membangun hipotesis, juga sangat diperlukan pada bagian pembahasan hasil penelitian.

Kata Kunci: Kepuasan kerja, Kinerja, Mutasi Pegawai, Penempatan Pegawai.

\section{INTRODUCTION}

\section{Latar Belakang Masalah.}

Menurut Wayne C. Parker (1996:3) terdapat lima manfaat pengukuran kinerja suatu entitas pemerintahan, yaitu, meningkatkan mutu pengambilan keputusan. Seringkali keputusan yang diambil pemerintah dilakukan dalam keterbatasan data dan berbagai pertimbangan politik serta tekanan dari pihak-pihak yang berkepentingan. Proses pengembangan pengukuran kinerja ini akan memungkinkan pemerintah untuk menentukan misi dan menetapkan tujuan pencapaian hasil tertentu. Karena itu dapat dipilih metode pengukuran kinerja untuk melihat kesuksesan program yang ada. sehingga, adanya pengukuran kinerja membuat pihak legislatif dapat fokus terhadap hasil yang didapat, memberikan evaluasi terhad ap pelaksanaan anggaran juga melakukan diskusi mengenai program baru yang akan diusulkan. Pengukuran kinerja meningkatkan akuntabilitas internal. Dengan adanya pengukuran kinerja maka akan tercipta akuntabilitas di semua lini pemerintahan, dari lini bawah hingga lini teratas. Lini teratas pun kemudian dapat bertanggungjawab kepada pihak legislatif. Pengukuran kinerja meningkatkan akuntabilitas publik. Meskipun bagi sebagian pihak, pelaporan evaluasi kinerja pemerintah kepada masyarakat dirasakan cukup menakutkan, namun publikasi laporan ini sangat penting dalam keberhasilan sistem pengukuran kinerja yang baik. Keterlibatan masyarakat terhadap 
pengambilan kebijakan pemerintah menjadi semakin besar dan kualitas hasil suatu program juga semakin diperhatikan.

Pengukuran kinerja mendukung perencanaan stategi dan penetapan tujuan. Proses perencanaan strategi dan tujuan akan kurang berarti tanpa ad anya kemampuan untuk mengukur kinerja dan kemajuan suatu program. Tanpa ukuran-ukuran ini, kesuksesan suatu program juga tidak pernah akan dinilai dengan obyektif.

Pengukuran kinerja memungkinkan suatu entitas untuk menentukan penggunaan sumber daya secara efektif. Masyarakat semakin kritis untuk menilai program-program pokok pemerintah sehubungan dengan meningkatnya pajak yang dikenakan kepada mereka. Evaluasi yang dilakukan cenderung mengarah kepada penilaian apakah pemerintah memang dapat memberikan pelayanan yang terbaik kepada masyarakat. Dalam hal ini pemerintah juga mempunyai kesempatan untuk menyerahkan sebagian pelayanan publik kepada sektor swasta dengan tetap bertujuan untuk memberikan pelayanan yang terbaik.

Artikel ini khusus membahas pengaruh Mutasi Pegawai dan Penempatan Pegawai terhadap Kepuasan Kerja dan dampaknya terhadap Kinerja Pegawai, (Suatu Studi Literatur Manajemen Sumberdaya Manusia). Tentu tidak semua faktor yang mempengaruhi Kepuasan Kerja dan Kinerja Pegawai pada artikel ini, ini hanya sebagian kecil saja yang akan di kaji dan di review.

Secara rinci tujuan dari penulisan "Literature Review Paper" ini adalah mengetahui pengaruh atau hubungan antara variabel exogen Mutasi Pegawai Dan Penempatan Pegawai terhadap variabel endogen Kepuasan Kerja dan Kinerja Pegawai.

1) Pengaruh atau hubungan Mutasi Pegawai terhadap Kepuasan Kerja

2) Pengaruh atau hubungan Penempatan Pegawai terhadap Kepuasan Kerja

3) Pengaruh atau hubungan Mutasi Pegawai terhad ap Kinerja Pegawai

4) Pengaruh atau hubungan Penempatan Pegawai terhadap Kinerja Pegawai

5) Pengaruh atau hubungan Kepuasan Kerja terhadap Kinerja Pegawai

\section{KAJIAN TEORI}

\section{Kepuasan Kerja}

Kepuasan kerja ialah tingkat kesenangan yang dirasakan seseorang terhadap peranan serta pekerjaannya di suatu organisasi. Tingkat rasa puas individu bahwa mereka mendapat imbalan yang setimpal dari bermacam-macam aspek situasi pekerjaan dari organisasi tempat mereka bekerja. Jadi kepuasan kerja menyangkut psikologis individu didalam organisasi, yang diakibatkan oleh keadaan yang ia rasakan dari lingkungannya. Davis dan Newstrom $(1985 ; 105)$ mendeskripsikan "kepuasan kerja adalah seperangkat perasaan pegawai tentang menyenangkan atau tidaknya pekerjaan mereka".

Menurut Kreitner dan Kinicki $(2001 ; 271)$ kepuasan kerja adalah "suatu efektifitas atau respons emosional terhadap berbagai aspek pekerjaan”. Menurut Robbins $(2003 ; 78)$ kepuasan kerja adalah "sikap umum terhadap pekerjaan seseorang yang menunjukkan perbedaan antara 
jumlah penghargaan yang diterima pekerja dan jumlah yang mereka yakini seharusnya mereka terima”. Kepuasan kerja merupakan respon afektif atau emosional terhadap berbagai segi atau aspek pekerjaan seseorang sehingga kepuasan kerja bukan merupakan konsep tunggal. Seseorang dapat relatif puas dengan salah satu aspek pekerjaan dantidak puas dengan satu atau lebih aspek lainnya. Kepuasan Kerja merupakan sikap (positif) tenaga kerja terhadap pekerjaannya, yang timbul berdasarkan penilaian terhadap situasi kerja. Penilaian tersebut dapat dilakukan terhadap salah satu pekerjaannya, penilaian dilakukan sebagai rasa menghargai dalam mencapai salah satu nilai-nilai penting dalam pekerjaan. Karyawan yang puas lebih menyukai situasi kerjanya daripada tidak menyukainya.

Variabel Kepuasan Kerja ini sudah banyak di teliti oleh peneliti sebelumnya, diantaranya adalah Setioningtyas, Widhayani Puri \& Dyatmika, Sutama Wisnu (2020); Nur, Saina (2013); Harahap, Sandhi Fialy \& Tirtayasa, Satria (2020); Putri, Adelia Trisna (2015)

\section{Kinerja Pegawai}

Kinerja pegawai merupakan suatu hasil yang dicapai oleh pegawai tersebut dalam pekerjaanya menurut kriteria tertentu yang berlaku untuk suatu pekerjaan tertentu. Menurut Robbins (2003) bahwa kinerja pegawai adalah sebagai fungsi dari interaksi antara kemampuan dan motivasi. Dalam studi manajemen, kinerja pegawai adalah hal yang memerlukan pertimbangan yang sangat penting sebab kinerja individual seorang pegawai dalam suatu organisasi merupakan bagian dari kinerja organisasi tersebut, dan dapat menentukan kinerja dari organisasi itu sendiri. Berhasil atau tidaknya kinerja pegawai yang dicapai oleh organisasi tersebut akan dipengaruhi oleh kinerja dari pegawai secara individu maupun kelompok.

Kinerja seringkali dipikirkan sebagai pencapaian tugas, dimana istilah tugas sendiri berasal dari pemikiran aktifitas yang dibutuhkan oleh pekerja (Gibson, 1997). Yukl (1998) memakai istilah proficieny yang mengandung arti yang lebih luas. Kinerja mencakup segi usaha, loyalitas, potensi, kepemimpinan, dan moral kerja. Profisiensi dilihat dari tiga segi, yaitu: perilaku-perilaku yang ditunjukan seseorang dalam bekerja, hasil nyata atau outcomes yang dicapai pekerja, dan penilaian-penilaian pada faktor-faktor seperti motivasi, komitmen, inisiatif, potensi kepemimpinan dan moral kerja. Gibson (1997) mendefinisikan kinerja sebagai hasil dari pekerjaan yang terkait dengan tujuan organisasi seperti, kualitas, efesiensi, dan kriteria efektifitas lainya. Kinerja merefleksikan seberapa baik dan seberapa tepat seorang individu memenuhi permintaan pekerjaan. 
Henry Simamora dalam bukunya Manajemen Sumber Daya Manusia (1995;325) mengemukakan bahwa kinerja pegawai adalah tingkat dimana para karyawan/pekerja mencapai persyaratan-persyaratan pekerjaan. Sedangkan menurut August W.Smith yang dikutip oleh Sedarmayanti dalam bukunya Sumber Daya Manusia dan Produktivitas Kerja(2001:50) adalah sebagai berikut: "Kinerja pegawai adalah merupakan hasil atau keluaran dari suatu proses".

Dari pengertian tersebut dapat disimpulkan bahwa kinerja merupakan pencapaian tugas oleh seseorang pegawai yang menjadi fungsi dari interaksi antara kemampuan dan motivasi sebagai hasil dari pekerjaan terkait tujuan organisasi atau merupakan keluaran dari proses suatu pekerjaan.

Variabel Kinerja Pegawai ini sudah banyak di teliti oleh peneliti sebelumnya, diantaranya adalah Sari, T Tika Novita (2020); Nur, Saina (2013); Harlie, M (2013); Nasrudin Wibowo, Sandi (2018)

\section{Mutasi Pegawai}

(Gunawan et al., 2017) menyebutkan mutasi merupakan kegiatan memindahkan tenaga kerja dari suatu tempat ke tempat kerja yang lainnya, akan tetapi mutasi sebenarnya tidak selamanya sama dengan pemindahan. Mutasi meliputi kegiatan memindahkan tenaga kerja atau pengalihan tanggung jawab, pemindahan status ketenagakerjaan dan sejenisnya, sedangkan pemindahan hanya terbatas pada mengalihan tenaga kerja dari suatu tempat ke tempat lainnya. Salah satu perwujudan mutasi adalah pemindahan tenaga kerja dari suatu tempat ketempat yang lainnya.

Selanjutnya, (Kadarisman, 2012) mutasi adalah kegiatan ketenagakerjaan yang berhubungan dengan proses pemindahan fungsi, tangung jawab, dan status ketenagakerjaan tenaga kerja ke situasi tertentu dengan tujuan agar tenaga kerja yang bersangkutan memperoleh kepuasan kerja yang mendalam dan dapat memberikan prestasi kerja yang semaksimal mungkin kepada perusahaan.

Menurut (Hasibuan, 2019) menyatakan bahwa mutasi adalah suatu perubahan posisi atau jabatan atau tempat atau pekerjaan yang dilakukan baik secara horizontal maupun vertikal (promosi/demosi) di dalam suatu organisasi. Lebih lanjut (Hasibuan, 2019) menyatakan bahwa pada dasarnya mutasi termasuk dalam fungsi pengembangan pegawai, karena tujuannya adalah untuk meningkatkan efisiensi dan efektivitas kerja dalam organisasi tersebut. 
Sehingga dapat disimpulkan mutasi pegawai adalah pemindahan tenaga kerja dari suatu tempat ke tempat lain yang mana termasuk pemindahan fungsi, tanggaungjawab, status ketenagakerjaan yang dilakukan secara horizontal maupun vertikal dengan berbagai tujuan.

Variabel Mutasi Pegawai sudah banyak di teliti oleh peneliti sebelumnya di antaranya adalah Setioningtyas, Widhayani Puri \& Dyatmika, Sutama Wisnu (2020); Ambarita, Arnimisari Juliana \& Ridho, Hatta (2016); Putri, Adelia Trisna (2015).

\section{Penempatan Pegawai}

Hasibuan (2010:62) penempatan pegawai berpedoman kepada prinsip penempatan orang-orang yang tepat dengan tempat yang tepat dan penempatan orang yang tepat untuk jabatan yang tepat atau the rignt man in the right place and the right man behind in the right job. Penempatan yang tepat dapat terlihat dari latar belakang pendidikan SDM, kesehatan jasmani dan rohani, pengalaman kerja, umur SDM yang bersangkutan, jenis kelamin, status perkawinan, minat dan hobi (Saydam, 1996:222). Selain itu, Sculler (1997:276) mengemukakan bahwa penempatan berkaitan dengan pencocokan seseorang dengan jabatan dan pengetahuan, keterampilan, pengetahuan, referensi dan kepribadian pegawai tersebut.

Siswanto(2005:32) mendefinisikan penempatan adalah proses pemberian tugas dan pekerjaan kepada tenaga kerja yang lulus seleksi untuk dilaksanakan sesuai ruang lungkup yang telah ditetapkan, serta mampu mempertanggung jawabkan segala resiko dan kemungkinan-kemungkinan yang terjadi atas tugas dan pekerjaan, wewenang serta tanggung jawabnya. Mathis \& Jackson (2006:262) mendefinisikan penempatan adalah menempatkan posisi seseorang ke posisi pekerjaan yang tepat, seberapa baik seorang karyawan cocok dengan pekerjaanya akan mempengaruhi jumlah dan kualitas pekerjaan. Uraian sebelumnya dapat disimpulkan penempatan adalah suatu proses pemberian tugas dan pekerjaan kepada tenaga kerja yang lulus dalam seleksi sesuai minat, bakat, pendidikan, dan prestasi yang dimiliki dengan persyaratan yang dibutuhkan organisasi

Variabel Penempatan Pegawai sudah banyak di teliti oleh peneliti sebelumnya di antaranya adalah Sari, T Tika Novita (2020); Nasrudin Wibowo, Sandi (2018); Taniantari, Yuni (2019); Yona, Mira \& Yulita, Cut Della (2019); Oktaria, Ayu (2020).

\section{METODE PENULISAN}

Metode penulisan artikel ilmiah ini adalah dengan metode kualitatif dan studi literature atau Library Research. Mengkaji Buku-buku literature sesuai dengan teori yang di bahas khusunya di lingkup Manajemen Sumberdaya Manusia (MSDM). Disamping itu menganalisis 
artikel-artikel ilmiah yang bereputasi danjuga artikel ilmiah dari jurnal yang belum bereputasi. Semua artikel ilmiah yang di citasi bersumber dari Mendeley dan Scholar Google.

Dalam penelitian kualitatif, kajian pustaka harus digunakan secara konsisten dengan asumsi-asumsi metodologis. Artinya harus digunakan secara induktif sehingga tidak mengarahkan pertanyaan-pertanyaan yang diajukan oleh peneliti. Salah satu alasan utama untuk melakukan penelitian kualitatif yaitu bahwa penelitian tersebut bersifat eksploratif, (Ali \& Limakrisna, 2013).

Selanjutnya dibahas secara mendalam pada bagian yang berjudul" Pustaka Terkait" (Related Literature) atau Kajian pustaka( "Review of Literature"), sebagai dasar perumusan hipotesis dan selanjutnya akan menjadi dasar untuk melakukan perbandingan dengan hasil atau temuan-temuan yang terungkap dalam penelitian, (Ali \& Limakrisna, 2013).

\section{PEMBAHASAN}

\section{Hubungan antara Mutasi Pegawai terhadap Kepuasan Kerja}

Mutasi adalah kegiatan memindahkan tenaga kerja atau pegawai dari satu tempat ke tempat yang lain. Adapun indikator untuk mengukur variabel mutasi antara lain: Pengalaman, Pengetahuan, Kebutuhan, Kecakapan, dan Tanggung jawab. Kepuasan Kerja adalah bentuk perasaan dari pegawai terkait pekerjaan, Adapun indikator untuk mengukur variabel tersebut yakni: pilihan produk, pilihan merek, pilihan pembayaran (gaji dan upah), pekerjaan itu sendiri, rekan kerja, promosi dan pengawasan

Mutasi jabatan dilakukan dengan tujuan untuk memberikan kesempatan kepada karyawan untuk mengembangkan potensi yang dimiliki dibidang pekerjaan lain dan juga berguna untuk pengayaan pengetahuan bagi karyawan itu sendiri. Apabila seorang pegawai diberi kesempatan untuk pengayaan pengetahuan, tentu hal tersebut merupakan suatu kepuasan kerja yang dirasakan oleh karyawan tersebut, shingga dapat disimpulkan bahwa mutasi berpengaruh terhadap kepuasan kerja pegawai.

Variabel Mutasi Pegawai dan Kepuasan Kerja sudah banyak di teliti oleh peneliti sebelumnya di antaranya adalah Setioningtyas, Widhayani Puri \& Dyatmika, Sutama Wisnu (2020); Putri, Adelia Trisna (2015); Pramudya, Rizma Rahmad (2020); Ambarita, Arnimisari Juliana \& Ridho, Hatta (2016) yang menunjukkan bahwa mutasi pegawai berpengaruh terhad ap kepuasan kerja.

\section{Hubungan antara Penempatan Pegawai terhadap Kepuasan Kerja}


Kusuma, I. P. S. W., \& Ardana, K. (2014). mengatakan semakin baik penempatan yang dilakukan oleh perusahaan, maka semakin puas karyawan dalam bekerja, sehingga berdampak terhadap kinerja karyawan yang semakin baik

Karmita, S. B., Supartha, I. W. G., \& Priantini, P. S. (2015). Dalam "Pengaruh motivasi kerja dan penempatan karyawan terhadap kepuasan kerja dan kinerja karyawan (studi pada analis kredit PT. BPD Bali Cabang Utama Denpasar)" menyimpulkan. Penempatan karyawan berpengaruh positif terhadap kepuasan kerja karyawan. Hal ini berarti bahwa semakin sesuai penempatan karyawan dengan latar belakang pendidikannya, maka kepuasan kerja karyawan akan semakin tinggi. Minat dan bakat terhadap pekerjaan dan kesesuaian pengetahuan memberikan pengaruh yang besar terhadap penempatan karyawan di bidang analis kredit.

Variabel Penempatan Pegawai dan Kepuasan Kerja sudah banyak di teliti oleh peneliti sebelumnya di antaranya adalah Karmita, S B \& Supartha, I W G (2015); Kusuma, I \& Ardana, Komang (2014); Pramudya, Rizma Rahmad (2020)

\section{Hubungan antara Mutasi Pegawai terhadap Kinerja Pegawai}

Aditianto, D., Sihite, M., \& Supriyadi, E. (2020) Mutasi adalah bahwa dengan adanya mutasi pegawai dapat meningkatkan pengetahuan dan kemampuan dari pegawai dari segi kualitas dan kuantitas. Sejalan dengan itu,juga memperkuat bahwa keuntungan atas adanya mutasi pegawai adalah memperluas cakupan pekerjaan yang dapat dilakukan oleh para pegawai dan sarana untuk lebih mengembangkan diri pegawai. Hal ini berarti pegawai akan terdorong untuk bekerja lebih baik dalam mencapai karier yang lebih tinggi. Dari sisi organisasi, mutasi pegawai digunakan untuk menstimulasi pegawai agar dapat mengeluarkan potensi mereka.

Dengan luasnya cakupan pekerjaan yang dilakukan oleh pegawai dan pegawai memiliki sarana untuk mengembangkan diri yang mendorong pegawai untuk mencapai karir yang lebih tinggi akan mendorong pegawai untuk meningkatkan kinerjanya untuk mencapai hal tersebut. Sehingga mutasi pegawai mempengaruhi kinerja pegawai.

Variabel Mutasi Pegawai Dan Kinerja Pegawai sudah banyak di teliti oleh peneliti sebelumnya di antaranya adalah Prasetyo, A \& Sularso, R \& Handriyono, H (2018); Chrishartanto, Riyadi (2019); Setioningtyas, Widhayani Puri \& Dyatmika, Sutama Wisnu (2020)

\section{Hubungan antara Penempatan Pegawai terhadap Kinerja Pegawai}

Siswanto (2012) menyatakan bahwa penempatan kerja adalah suatu urutan yang kronologis untuk menempatkan pegawai yang tepat pada posisi yang tepat. Hasil penelitian ini menunjukan bahwa adanya kesesuaian dari hasil penelitian dari Montalalu, et al (2016) yang 
menyebutkan bahwa semakin baik penempatan pegawai, maka semakin baik pula kinerja pegawai tersebut.

Berdasarkan hasil penelitian terdapat hubungan yang signifikan (berarti) antara penempatan pegawai dengan kinerja guru. Hasil penelitian ini diperkuat oleh pendapat Wibowo (2007:67) untuk mencapai kinerja yang baik salah satu hal yang harus diperhatikan yaitu dari proses penempatan sumber daya manusia. Siswanto (2002:163) Penempat an pegawai akan mampu meningkatkan kinerja pegawai. Pendapat diatas menjelaskan bahwa pegawai yang memiliki kinerja yang baik akan lebih banyak memberikan sumbangan pada pencapaian tujuan organisasi kearah yang lebih baik. Apabila penempatan pegawai tepat akan menjadi pendorong dalam meningkatkan kinerja kinerja pegawai. Hal yang demikian perlu diperhatikan pimpinan dalam meningkatkan kinerja pegawai dengan penempatan pegawai yang tepat akan mempengaruhi pegawai untuk melaksanakan tugas dan pekerjaan secara optimal

Variabel Penempatan Pegawai dan Kinerja Pegawai sudah banyak diteliti oleh peneliti sebelumnya di antaranya adalah Sari, T Tika Novita (2020); Karmita, S B \& Supartha, I W G (2015); Kusuma, I \& Ardana, Komang (2014)

\section{Hubungan antara Kepuasan Kerja terhadap Kinerja Pegawai}

(Nabawi, 2019) Kepuasan Kerja berpengaruh positif dan signifikan terhadap kinerja pegawai, Semakin baik kepuasan kerja maka semakin baik kinerja pegawai. Nasuka et al.(2017), Sibasopait (2018) dan Mandala and Dihan (2018) yang mengemukakan bahwa kepuasan kerja berpengaruh positif terhadap kinerja karyawan. Apabila karyawan kepuasan kerjanya meningkat maka akan meningkatkan kinerjanya karyawan. Kinerja pegawai akan meningkat apabila pegawai mendapatkan kepuasan kerja dengan baik. Yang berarti bahwa kepuasan kerja memiliki hubungan dengan kinerja pegawai.

Variabel Kepuasan Kerja dan Kinerja Pegawai sudah banyak di teliti oleh peneliti sebelumnya di antaranya adalah Harahap, Sandhi Fialy \& Tirtayasa, Satria (2020); Afnita, Afnita (2020); Kusuma, I \& Ardana, Komang (2014); Nabawi, Rizal (2019).

\section{Conceptual Framework}

Berdasarkan rumusan masalah penulisan artikel ini dan kajian studi literature review baik dari buku dan artikel yang relevan, maka di peroleh rerangka artikel ini seperti di bawah ini. 


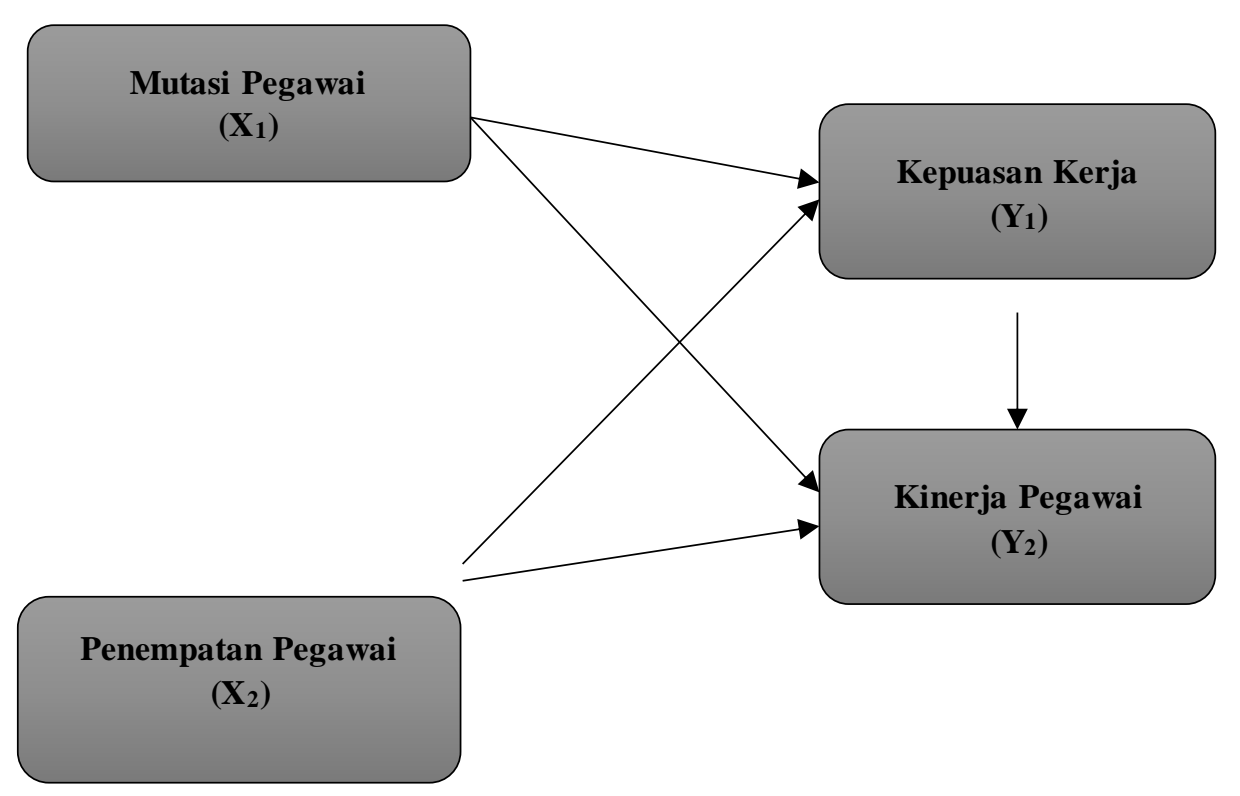

Gambar 1: Conceptual Framework

Berdasarkan Kajian teori dan review hasil dari artikel yang relevan serta gambar dari conceptual framework, maka: Mutasi Pegawai dan Penempatan Pegawai berpengaruh terhad ap Kepuasan Kerja dan Kinerja Pegawai baik secara langsung maupun tidak langsung.

\section{KESIMPULAN DAN SARAN}

\section{Kesimpulan}

Berdasarkan rumusan artikel, hasil dan pembahasan, maka dapat di di rumuskan hipotesis untuk riset selanjutnya:

1. Mutasi Pegawai berpengaruh terhadap Kepuasan Kerja.

2. Penempatan Pegawai berpengaruh terhadap Kepuasan Kerja.

3. Mutasi Pegawai berpengaruh terhadap Kinerja Pegawai.

4. Penempatan Pegawai berpengaruh terhadap Kinerja Pegawai.

5. Kepuasan Kerja berpengaruh terhadap Kinerja Pegawai.

\section{Saran}

Berdasarkan Kesimpulan di atas, maka saran pada artikel ini adalah bahwa masih banyak factor lain yang mempengaruhi Kepuasan Kerja dan Kinerja Pegawai, selain dari Mutasi Pegawai dan Penempatan Pegawai pada semua tipe dan level organisasi atau perusahaan, oleh karena itu masih di perlukan kajian yang lebih lanjut untuk mencari faktor-faktor lain apa saja 
yang dapat memepengaruhi Kepuasan Kerja dan Kinerja Pegawai selain yang di teliti pada arikel ini.

\section{DAFTAR RUJUKAN:}

Afnita, A. (2020). ANALISIS KECERDASAN SPIRITUAL SEBAGAI PEMODERASI ANTARA KEPUASAN KERJA TERHADAP KINERJA PEGAWAI BALAI BESAR PELATIHAN PETERNAKAN BATU (Doctoral dissertation, Universitas Muhammadiyah Malang).

Andini, R. (2010). Analisis pengaruh kepuasan gaji, kepuasan kerja, komitmen organisasional terhad ap turnover intention. Dinamika Sains, 8(16).

Anita, J., Aziz, N., \& Yunus, M. (2013). Pengaruh penempatan dan beban kerja terhadap motivasi kerja dan dampaknya pada prestasi kerja pegawai dinas tenaga kerja dan mobilitas penduduk aceh. Jurnal Manajemen Pascasarjana Universitas Syiah Kuala, 2(1), $67-77$.

Bahri, S. (2019). Pengaruh Penempatan, Motivasi, Dan Lingkungan Kerja Terhadap Kinerja Pegawai. Maneggio: Jurnal Ilmiah Magister Manajemen, 2(1), 16-30.

Chrishartanto, R. (2019). Pengaruh Kompetensi, Motivasi dan Mutasi Pegawai Terhadap Kinerja Pegawai Pada Kantor Pelayanan Pajak Pratama Makassar Barat. Jurnal Ilmu Ekonomi, $2(2)$, $133-147$. http://jurnal.fe.umi.ac.id/index.php/PARADOKS/article/view/122

Dotulong, L., Lapian, J., \& Runtunuwu, H. J. (2015). Pengaruh Disiplin, Penempatan dan Lingkungan Kerja terhadap Kinerja Pegawai pada Badan Pelayanan Perizinan Terpadu Kota Manado. Jurnal Riset Ekonomi, Manajemen, Bisnis dan Akuntansi, 3(3), 2674.

Fadilah, A. N. (2013). Pengaruh Penempatan Pegawai Terhadap Kinerja (Studi pada Pegawai Sekretariat Daerah Kabupaten Gresik). Jurnal Administrasi Publik, 1(5), 847-852.

Hasibuan, S. . M. (2006). Organisasi dan Motivasi - Dasar Peningkatan Produktivitas. In Bumi Aksara Jakarta.

Karmita, S. B., Supartha, I. W. G., \& Priantini, P. S. (2015). Pengaruh motivasi kerja dan penempatan karyawan terhadap kepuasan kerja dan kinerja karyawan (studi pada analis kredit PT. BPD Bali Cabang Utama Denpasar). E-Jurnal Ekonomi dan Bisnis Universitas Udayana, 4, 947-974.

Kusuma, I. P. S. W., \& Ardana, K. (2014). Pengaruh Penempatan dan Kompensasi Terhadap Kepuasan Kerja dan Kinerja Karyawan (Doctoral dissertation, Udayana University). 
Nabawi, R. (2019). Pengaruh Lingkungan Kerja, Kepuasan Kerja dan Beban Kerja Terhadap Kinerja Pegawai. Maneggio: Jurnal Ilmiah Magister Manajemen, 2(2), 170-183. https://d oi.org/10.30596/maneggio.v2i2.3667

Nabawi, R. (2020). Pengaruh Lingkungan Kerja, Kepuasan Kerja dan Beban Kerja Terhadap Kinerja Pegawai. Maneggio: Jurnal Ilmiah Magister Manajemen, 2(2), 170-183.

Nguyen, P. T., Yandi, A., \& Mahaputra, M. R. (2020). Factors That Influence Employee

Performance: Motivation, Leadership, Environment, Culture Organization, Work Achievement, Competence And Compensation (A Study Of Human Resource Management Literature Studies). Dinasti International Journal of Digital Business Management, 1(4), 645-662.

Oktaria, A. (2020). Hubungan Penempatan Pegawai dengan Kinerja Pegawai di Kantor Dinas Sosial Provinsi Sumatera Barat. Jurnal Bahana Manajemen Pendidikan, 1(1).

Parker, Wayne C. (1993). Performance Measurement in the Public Sector. State of Utah. www.rutgers.edu/Accounting/raw/seagov/pmg/perfmeasure, September 2000.

Priyadi, D. T., Sumardjo, M., \& Mulyono, S. I. (2020). PENGARUH KEPUASAN KERJA, KOMITMEN ORGANISASIONAL, DAN JOB INSECURITY TERHADAP ORGANIZATIONAL CITIZENSHIP BEHAVIOUR (OCB)(STUDI PADA PEGAWAI NON-PNS KEMENTERIAN SOSIAL RI). Jurnal Ilmu Manajemen Terapan, 2(1), 10-22. Simamora, H. (2004). Manajemen sumber daya manusia. Yogyakarta: Bagian Penerbitan STIE YPKN, 2004. https://opac.perpusnas.go.id/DetailOpac.aspx?id=553197

Syah, A., Mattalatta, \& Ilyas, G. B. (2017). PENGARUH BUDAYA ORGANISASI, MUTASI, MOTIVASI TERHADAP KINERJA PEGAWAI NEGERI SIPIL PADA KANTOR DISTRIK NAVIGASI KELAS I MAKASSAR. Jurnal Mirai Management, 2(2), 215-230. https://doi.org/10.1234/MIRAI.V2I2.52.

Yunita, Y., Kumbara, V. B., \& Neldi, M. (2020). PENGARUH PERSEPSI KARYAWAN TENTANG PENILAIAN KINERJA DAN KOMPENSASI FINANSIAL TERHADAP KEPUASAN KERJA KARYAWAN PT. SEMEN PADANG. Jurnal Ekonomi Manajemen Sistem Informasi, 2(1), 61-80.

Zahari, M., Yamali, F. R., \& Irfani, A. (2020). Pengaruh Gaya Kepemimpinan Kepemimpinan dan Penempatan Pegawai Terhadap Motivasi Kerja Serta Dampaknya Pada Kinerja Pegawai di Biro Umum Setda Provinsi Jambi. J-MAS (Jurnal Manajemen dan Sains), 5(2), 276-284. 